\title{
Implementation of Education Improvement Policies for the Indonesia-Papua New Guinea Border Area in Sota District, Merauke Regency
}

\author{
$1^{\text {st }}$ Albertus Yosep Maturan* \\ Department of State Administration \\ Science \\ Universitas Musamus \\ Merauke, Indonesia \\ albertmaturan@unmus.ac.id
}

\author{
$2^{\text {st }}$ David Laiyan \\ Department of State Administration \\ Science \\ Universitas Musamus \\ Merauke, Indonesia \\ davidlaiyan@unmus.ac.id
}

\author{
$3^{\text {st }}$ Welem Levi Betaubun \\ Department of State Administration \\ Science \\ Universitas Musamus \\ Merauke, Indonesia \\ masterholls@unmus.ac.id
}

\begin{abstract}
Education is a mirror of the future of the nation which is very basic to improve superior human resources in every existing sector. Industrial Revolution 4.0 is a challenge for all human beings, especially for the Indonesian nation which is a developing country where education is very important to advance the nation's civilization. Regulation of the Minister of Education and Culture of the Republic of Indonesia Number 28 of 2016 concerning the Quality Assurance System for Primary and Secondary Education as outlined in Chapter III, article 7, paragraph 3 of the regulation is very clear. The purpose of this research is to determine the extent of the role of central and local governments in improving the quality and quality of education in the Indonesian-Papua New Guinea border area in the Sota district of Merauke Papua Regency which is the Central line Between countries. The method used in this research is qualitative, the type of research is qualitative descriptive. The results showed that policies related to their education in the border area are still very lacking, so what is expected for educational progress in supporting the vision and mission of the central government is simply a dream for Indonesian citizens, especially those in the border area. Human resources that are expected to be superior through education are very good if not supported by the role of the central government and local governments in formulating a policy that is precisely targeted and adjusted to the geographical state As well as the character of the community in the border area, so it will run well education programs to create the Indonesian man who is superior and advanced in the era of the 4.0 Industrial Revolution. The mindset of people who still rely on nature as a source of life, especially in border areas must be changed by providing educational facilities and human resources that can support the course of the educational process to change the mindset of the community which has been considered wrong.
\end{abstract}

Keywords: implementation, policy, quality of education, the border area

\section{INTRODUCTION}

The progress of a nation can be seen from various aspects, especially in the aspect of education which is a benchmark for the progress of the country. Education is not just a policy made by the government, but a necessity carried out by the government to create superior resources in each country. Indonesia is a developing country, especially in the aspect of education which in fact is still not very good in the eyes of the world, this has become an important focus of the central government and regional governments to be able to improve the quality of education for the whole existing citizens.

The independence of the Indonesian people so far has not reflected significant progress related to the quality of existing education, especially in border areas, this is very apparent from the facilities and infrastructure that support the educational process, which is very different from urban areas which are very complete with educational infrastructure.

Decentralization clearly implies that to support sustainable development, there needs to be a mechanism for sharing and even handing over authority in a government from the central government to regional governments. This condition in principle is to provide maximum performance space to local governments in managing and managing all forms of resources (natural and human) that are owned effectively and efficiently to be used for the interests of their communities [1].

\section{RESEARCH METHODS}

\section{A. Types of research}

Qualitative research is research intended to understand phenomena about what is experienced by research subjects, for example, behavior, perception, motivation, action, etc. holistically (intact) and by means of descriptions in the form of words and language in a special natural context and by utilizing various natural methods. The method conducted in this research is the study of literature to find out about the conditions that exist in accordance with the data in the references used and associated with real conditions in the field. In this study, the analysis used is to identify existing problems. The identification results will then be used to formulate the aspects found in order to provide consideration and input to stakeholders. 


\section{B. Research sites}

This research was conducted in 5 (five) villages in Sota, Merauke, Sota, Yanggandur, Rawa Biru, Erambu, and Toray. The village is located on the borderline between countries, namely the Republic of Indonesia and neighboring Papua New Guinea (PNG).

\section{RESULTS AND DISCUSSION}

Availability of facilities and infrastructure is an important element in a service process, if a service is not supported by good facilities and infrastructure, the service process will not run as expected. Availability of means is everything that can be used as a tool in achieving goals and objectives, which means more aimed at moving objects such as computerization and machines. While infrastructure as the main support the implementation of an existing process.

\section{A. Education in Indonesia}

In 2014 Indonesia's education position was very poor. The Learning Curve Pearson 2014, a world education ranking agency explained that Indonesia was ranked last in the world quality of education. Whereas in 2015 the quality of education in Indonesia was still in 10 countries that had low quality education, the ranking was obtained from the Global School Ranking. Viewed from 2014 running into 2015 the quality of education in Indonesia can be said to have increased, although it did not experience a very significant increase.

\section{B. Education in the border area}

Education in the Border Region is very worrying, this is due to the lack of government attention in preparing supporting facilities and infrastructure for the implementation of the existing educational process. Merauke Regency is a border area between the Unitary State of the Republic of Indonesia which borders directly with neighboring Papua New Guinea (PNG) and also Australia. This should be of particular concern to the central and regional governments to focus more on the education aspect compared to other aspects, so that the human resources in the border area can be as advanced as other regions in Indonesia. The geographical situation of the border area in Merauke Regency has always been an obstacle for teachers who work in schools in the border area, so the education process is often neglected, especially coupled with binding rules for teachers to always leave school to meet the rules made by the central government in terms of teacher certification and so on. The need for a directed policy implementation so that the quality of education in the border areas, especially in the Sota District, Merauke Regency can run as it should so that the existing human resources can be on par with other regions in Indonesia in general.

Education was recognized by the Marind people in 1910 , in the Okaba district through a Christian mission, and only then were they able to read, write, get to know religion and begin to open up to the outside environment. Education in Merauke is complete from basic education to tertiary education, but what about people who live far from cities. Lack of infrastructure and transportation are constraints on children's desire to go to school and higher education. Indeed, there have been many attempts by the government to promote the Marind community, through (1) a transmigration program which aims to spread the population to remote areas of Papua, and teach Papuans to have other abilities to support their families, and familiarize themselves with other external environment; (2) human resource development programs, by providing the greatest opportunities for indigenous Papuans to obtain educational scholarships from the lowest to the highest level; and (3) granting special autonomy to Papua, where the central government gives authority to the regions to run the government with little intervention from the center and prioritizes the interests of local and indigenous Papuan people [2]

Talking about policy implementation can be seen in the fourth Model Merilee S. Grindele (1980), the approach is known as the Implementation as Political and Administrative Process. The first, seen from the process, and the second, whether the policy objectives are achieved, namely: Impact or effect on the community individually and in groups, and the level of change that occurs and the acceptance of target groups and the changes that occur [3].

The education process in the border area has been running as it should, but still constrained in supporting facilities and infrastructure in the process of running education and teaching in existing schools, especially in the border area in the Sota District of Merauke Regency. A teaching and learning process will run well if supported by good and complete facilities and infrastructure in educating the nation's children who are in the border area.

Implementation of a policy must have a direct impact on the community as the recipient of the policy, so that what is planned by the government will be achieved according to the targets set previously. The fact or the facts that exist in the field can be seen that there are still many school-age children who have not completed their education following the expectations of the government, this issue must be taken seriously by the central and regional governments, so that the government's expectations of superior human resources can be achieved according to expectations.

The policy on education will go well if looking at the social conditions of the people in the border area, so that its implementation is on target and the level of change will happen on its own, therefore special studies are needed to find out what is needed by the special community living in the border area in terms of education for their children and also for people who want to follow the same package A, B and $\mathrm{C}$ to advance the human resources expected by the government.

Through field observations, it can be seen that education in the border regions of the Unitary Republic of Indonesia and Papua New Guinea (PNG), especially in the Sota District, has very few supporting facilities, so that to achieve the hope of a country boy from eastern Indonesia is still far from expectations for the creation of Human Resources superior. The Central Government's program in supporting President Jokowi's Vision and Mission is now very good to be implemented throughout Indonesia, especially in the border areas in the Sota District of Merauke Regency.

Speaking of superior human resources, we will certainly talk about adequate education, education as an absolute thing for every Indonesian citizen because it is guaranteed in the 1945 Constitution of the Republic of Indonesia in Article 31 Paragraph 1 to Paragraph 5 the explanation is very clear, therefore education is the best way to improve the standard of living of a generation including Indonesia. 
Where the Unitary State of the Republic of Indonesia is one of the countries that have a diversity in various dimensions of life, both socio-cultural, political, economic strata, as well as geographical conditions and the vast natural topography. The differences that the Indonesian people have on one hand are a source of pride, but on the other hand they are an obstacle in carrying out the nation's development wheels, especially development in the world of education especially in the border areas of Merauke Regency which still requires more attention from the central government [4].

Seeing from the phenomena that exist, especially education, that education in Indonesia has not been evenly distributed as a whole. It can be seen that the gap in the quality of education between cities and border areas is still high. There are still many schools in the border areas that have not received special attention from the Central Government, this is an obstacle in moving towards Advanced Indonesia and Superior Resources following President Jokowi's Vision and Mission in his current administration. The difference is very visible from the physical buildings of magnificent schools in urban areas with complete teaching and learning facilities and infrastructure that become mandatory. However, all of that becomes rare when we compare it with the condition of schools in the border area, especially in the Sota District of Merauke Regency.[5]

Papua Province is a Special Autonomous Region, since 2001 until now the Special Autonomy process has not been fully authorized by the Papuan people and especially the people in the border areas of Papua, so are the communities in the Sota District, Merauke Regency, Papua. The implementation of the Policy specifically to improve the quality of education has not been fully implemented well, so that the quality of education which is felt by the community in the stagnant border area.

Government Regulation Number 32 Year 2013 Concerning National Education Standards in article 1 point 9 reads; Facilities and Infrastructure Standards are criteria regarding learning spaces, places to exercise, places of worship, libraries, laboratories, workshops, playgrounds, places to be creative and recreation as well as other learning resources, needed to support the learning process, including the use of information and communication technology, matters above has not been fully seen in schools in the border area, especially in Sota District, Merauke Regency [6]. The Government Regulation clearly states the facilities and infrastructure to support the National Education Standards, but it has not yet reached schools in rural Papua, especially in the border regions of Indonesia and Papua New Guinea (PNG), Sota District, Merauke Regency.

Public policy is an action that has a specific purpose, which is carried out by government agencies and their staff and the community to solve a particular problem [7].

Policy Implementation about various activities directed at program realization [8]. The implementation of policies that are aimed at must prioritize the public interest, so that what has been planned by the government can run according to what it wants to achieve. Policies on the education aspect carried out by the central government sometimes do not look at the conditions and conditions of the region and the people who live in the border areas, this has caused the failure of the central government's strategic programs to be implemented in the regions, especially at the district level in the border areas. Equity in the aspect of education is inadequate and benefits have not yet been benefited for people who live on the border, let alone want to improve the quality of education, far from expectations.

\section{Data from the Central Statistics Agency}

It is clear that the facilities and infrastructures that support the improvement of the quality of education in the border regions, especially in the Sota District of Merauke Regency are based on data from the Central Statistics Agency (BPS) of Merauke Regency in 2017 as follows:

Seen from the data of the Central Statistics Agency (BPS) of Merauke Regency, particularly in Elementary Schools (SD) the number of schools, pupils, teachers, and student-teacher ratios according to villages in Sota District in 2016 are: 5 school buildings, 567 students, teachers as many as 35 people, Teacher and Student Ratios 16.20 in 5 villages in the Sota District.

From the data of the Central Statistics Agency (BPS) of Merauke Regency, particularly in junior high schools (SMP) the number of schools, students, teachers, and studentteacher ratios by village in Sota District in 2016 are: 3 school buildings, 221 students, teachers as many as 19 people, the teacher and student ratio of 11.63 in 5 villages in the Sota District.

Seen from the Central Statistics Agency (BPS) data of Merauke Regency, particularly in senior high schools (SMA) the number of schools, pupils, teachers, and studentteacher ratios according to villages in Sota District in 2016 is the absence of high schools in 5 villages in the Sota District.

Seen from the data of the Central Statistics Agency (BPS) of Merauke Regency, particularly in Vocational High Schools (SMK) The Number of Schools, Students, Teachers, and Student-Teacher Ratios by Village in Sota District in 2016 are: 1 School buildings, 116 students, There are 18 teachers, 6.44 teacher and student ratios in 5 villages in Sota District, namely Sota Village, Yanggandur Village, Rawa Biru Village, Erambu Village, and Toray Village.

\section{CONCLUSION}

Implementation of government policies have not been fully realized, especially in the aspect of education. Education in border areas is still very alarming, so that the available resources have not been able to compete with other regions in Indonesia. The process that has taken place so far has been good, but it is necessary to look at the impact felt by the community as the recipient of the policy so that special studies on education in border areas need to be carried out to improve the quality of education and superior human resources. In the data from the Central Statistics Agency (BPS) of Merauke above, it is clear that supporting facilities and infrastructure are still lacking, teaching staff are also still limited in number, so this has an impact on the progress of superior human development in the border areas, especially in the Sota District of Merauke Regency.

With the central government policy-oriented to improving the quality of education in border areas, it must be adjusted to the conditions of the region as well as the social conditions of the community so that the implementation of the policy on the education aspect can run in line with the expectations that have been planned by the central 
government in supporting President Jokowi's vision and mission. one of which is "Superior Human Resource Development" (HR).

\section{ACKNOWLEDGMENT}

Thankyou, we would like to say to Rector Universitas Musamus Merauke for this support to publish the results of our research.

\section{REFERENCES}

[1] M. Fitriani et al., "Local Communities On The Frontier: Impact of Environment, Population and Socio-Economic Changes in Sota District," vol. 226, no. Icss, hal. 1353-1357, 2020, doi: 10.2991/icss-18.2018.285.

[2] A. F. Adam, A. P. Jusuf, dan D. P. Saragih, "The power of identity and communal networks of Papua," IOP Conf. Ser. Earth Environ. Sci., vol. 343, no. 1, 2019, doi: 10.1088/17551315/343/1/012209.

[3] D. Laiyan, B. T. Harsanto, dan R. D. Puspita, "Implementasi Program Gerakan," vol. 7, no. 01, hal. 2012, 2012

[4] Suyitno, "Penelitian Kualitatif," J. Equilib., vol. 5 No. 9, hal. 18, 2009.

[5] P. A. Moento, A. P. Yusuf, A. F. Adam, E. E. Maturbongs, A. P. Tljlien, dan M. Yunus, "Policy to increase revenue of fishermen community," IOP Conf. Ser. Earth Environ. Sci., vol. 473, no. 1 2020, doi: 10.1088/1755-1315/473/1/012033.

[6] R. Adisasmita, Manajemen Pemerintah Daerah. Yogyakarta: Graha Ilmu, 2011.

[7] P. A. Moento, R. Kusumah, A. Betaubun, dan H. Oja, "Penguatan Kelompok Usaha Tani Berbasiskan Pemberdayaan Masyarakat Petani Padi," vol. 9, no. 1, hal. 25-34, 2020.

[8] A. P. Yusuf, A. Y. Maturan, dan D. P. Saragih, "Kualitas Pelayanan Program Prioritas Nasional Percepatan Pendaftaran Tanah Sistematis Lengkap," vol. 9, no. 1, hal. 1-11, 2020. 